OAK RIDGE

NATIONAL LABORATORY

MANAGED BY UT-BATTELLE

FOR THE DEPARTMENT OF ENERGY
ORNL/TM-2000/137

\section{Hydrofluoric Acid Corrosion Testing on Unplated and} Electroless Gold-Plated Samples

\author{
P. E. Osborne \\ A. S. Icenhour \\ G. D. Del Cul
}




\title{
HYDROFLUORIC ACID CORROSION TESTING ON UNPLATED AND ELECTROLESS GOLD-PLATED SAMPLES
}

\author{
P. E. Osborne \\ A. S. Icenhour \\ G. D. Del Cul
}

Date Published: August 2000

\author{
Prepared by \\ OAK RIDGE NATIONAL LABORATORY \\ Oak Ridge, Tennessee 37831-6285 \\ managed by \\ UT-Battelle, LLC \\ for the \\ U.S. DEPARTMENT OF ENERGY \\ under contract DE-AC05-00OR22725
}


, 


\section{CONTENTS}

LIST OF FIGURES $\ldots \ldots \ldots \ldots \ldots \ldots \ldots \ldots \ldots \ldots \ldots \ldots \ldots \ldots \ldots \ldots \ldots \ldots$

LIST OF TABLES $\ldots \ldots \ldots \ldots \ldots \ldots \ldots \ldots \ldots \ldots \ldots \ldots \ldots \ldots \ldots \ldots \ldots$ vii

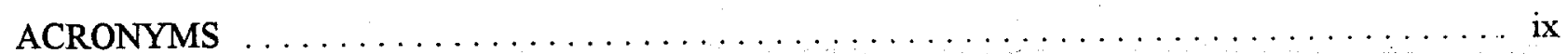

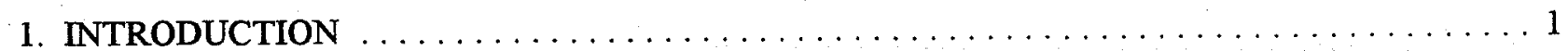

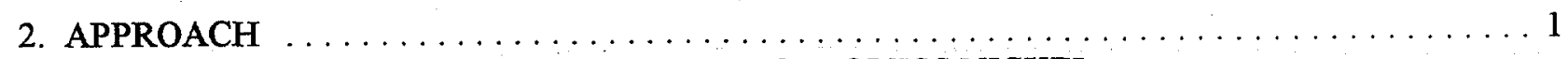

2.1 CARBON-STEEL COUPONS WITH ELECTROLESS NICKEL

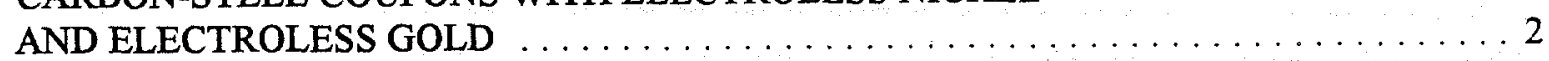

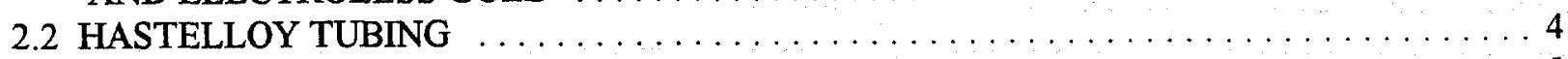

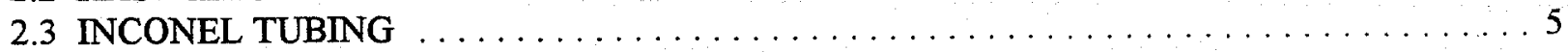

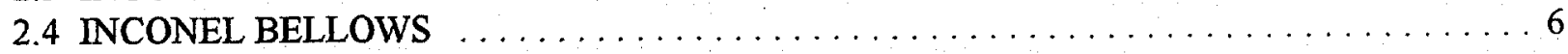

3. DISCUSSION $\ldots \ldots \ldots \ldots \ldots \ldots \ldots \ldots \ldots \ldots \ldots \ldots \ldots \ldots \ldots \ldots \ldots \ldots$ 



\section{LIST OF FIGURES}

Fig. 1. Results of corrosion tests of various alloys in $33 \mathrm{wt} \% \mathrm{HF}$ solution. $\ldots \ldots \ldots \ldots \ldots$ 



\section{LIST OF TABLES}

2.1. Results from $5-\mathrm{h}, 164-\mathrm{h}$, and 20 -d corrosion tests $\ldots \ldots \ldots \ldots \ldots \ldots \ldots \ldots \ldots \ldots$ 



\section{ACRONYMS}

MSRE Molten Salt Reactor Experiment

XRD X-ray diffraction 


\section{INTRODUCTION}

The Molten Salt Reactor Experiment (MSRE) remediation requires that almost $40 \mathrm{~kg}$ of uranium hexafluoride $\left(\mathrm{UF}_{6}\right)$ be converted to uranium oxide $\left(\mathrm{U}_{3} \mathrm{O}_{8}\right)$. In the process of this conversion, six moles of hydrofluoric acid (HF) are produced for each mole of $\mathrm{UF}_{6}$ converted. The entire conversion process can be summarized by the following reaction:

$$
\mathrm{UF}_{6}+3 \mathrm{H}_{2} \mathrm{O} \rightarrow \mathrm{UO}_{3}+6 \mathrm{HF}
$$

(The $\mathrm{UO}_{3}$ is not stable at high temperatures and therefore decomposes to $\mathrm{U}_{3} \mathrm{O}_{8}$ ). HF is well known for its ability to attack most metals and silica-containing compounds. It reacts rapidly to destroy protective films and can be fatal in very small quantities (e.g., $2 \%$ exposure of the body or $50 \mathrm{ppm}$ in air). Because most of the conversion system is made of various metals, the sections that come in contact with HF must be able to withstand corrosion, high temperatures, elevated pressures, and radiation. Consequently, most of these sections will be plated with gold for increased protection of the metal.

This report summarizes the results from the tests that were performed on the metal samples. Section 2 covers the approach to the tests, gives a general background of the sample preparation, and then reports the data from the tests. The final section presents a discussion of what was learned from the data and recommendations for uses of these metals in the MSRE conversion process.

\section{APPROACH}

A literature search provided little information on HF corrosion of various plated metals and of gold plating in particular. Therefore, it was decided to use metal samples that were plated with different thicknesses of electroless gold in a standard HF solution with a concentration of $33 \mathrm{wt} \%$. All plating was performed at Oak Ridge Industrial Plating in Oak Ridge, Tennessee. The samples were taken through a series of tests including (a) short-term exposure to HF at ambient temperatures, (b) exposure to hot HF, (c) heat drying, and (d) HF and air-drying cycles. An initial weight and intermediate weights during test exposures were taken and recorded. Any weight loss was then recorded. Care was taken not to contaminate the test samples with any other compound that might affect the plating or weight.

Samples were first run through a short-term test meant to determine resiliency and suitability for further testing. The samples were cleaned carefully with acetone before being hung on gold-plated hooks 
and then being submersed in individual beakers containing $33 \mathrm{wt} \% \mathrm{HF}$. Both samples and HF were heated to $60-70^{\circ} \mathrm{C}$ for $\sim 2 \mathrm{~h}$ and then cooled in ambient air for another $2-3 \mathrm{~h}$. Then, the samples were removed, rinsed well with water, dried, and weighed.

The intermediate-term test was begun immediately after completing the short-term test and was used to observe long-term interaction between HF and the samples. Samples were combined and submersed in a fresh $33 \mathrm{wt} \% \mathrm{HF}$ at ambient temperature for 1 week $(164 \mathrm{~h})$. Care was taken to keep them from coming into contact with one another or being agitated. Next, they were removed, rinsed with water, dried, and weighed. In an effort to better understand interaction and origination of large deposits on the samples and precipitation in the bottom of the vessel, a sample of precipitate was scraped off, rinsed, and submitted for $\mathrm{X}$-ray diffraction $(\mathrm{XRD})$ analysis.

Long-term testing was the final test that some samples were taken through. Only those samples that performed well in intermediate tests were taken through the long-term testing (except in the case of the bellows). This cyclic testing more closely simulated the expected exposure in the actual conversion process, although it was a harsher treatment than the materials are expected to receive in the process. The test involved a cycle of submersing the samples in the $33 \mathrm{wt} \% \mathrm{HF}$ solution for $18-20 \mathrm{~h}$ before removing them to air and heating to $\sim 40^{\circ} \mathrm{C}$ for $4-6 \mathrm{~h}$. Every few days the samples were carefully rinsed and dried in a vacuum oven before cooling and weighing. The results of those samples that were taken through all three sets of tests are summarized in Fig. 1. All samples were summarized in Table 2.1.

\subsection{CARBON-STEEL COUPONS WITH ELECTROLESS NICKEL AND ELECTROLESS GOLD}

The first samples to be tested were a group of six carbon-steel coupons $\sim 2 \mathrm{~cm}^{2}$ which had been plated with electroless nickel before being plated with electroless gold. The samples were plated with various thicknesses of gold from 5-30 $\mathrm{min}$ in 5-min increments. They were then weighed and submersed in $33 \mathrm{wt}$ $\% \mathrm{HF}$ for $1 \mathrm{~h}$. Samples and solution were then heated to $70^{\circ} \mathrm{C}$ for $1.75 \mathrm{~h}$ before they were allowed to cool and dry. All 6 samples retained their original weight, and there was no visible corrosion.

The coupon with the least plating ( 5 min of gold) was then resubmersed in $\mathrm{HF}$ and monitored for $7 \mathrm{~d}$ (intermediate testing). After $164 \mathrm{~h}$, it was removed, rinsed, weighed, and examined for corrosion. Although it had lost $0.0029 \mathrm{~g}(0.18 \mathrm{wt} \%)$ of its weight, it had no visual evidence of corrosion, and the weight loss was deemed inconsequential. 
ORNL DWG 2000-03949R

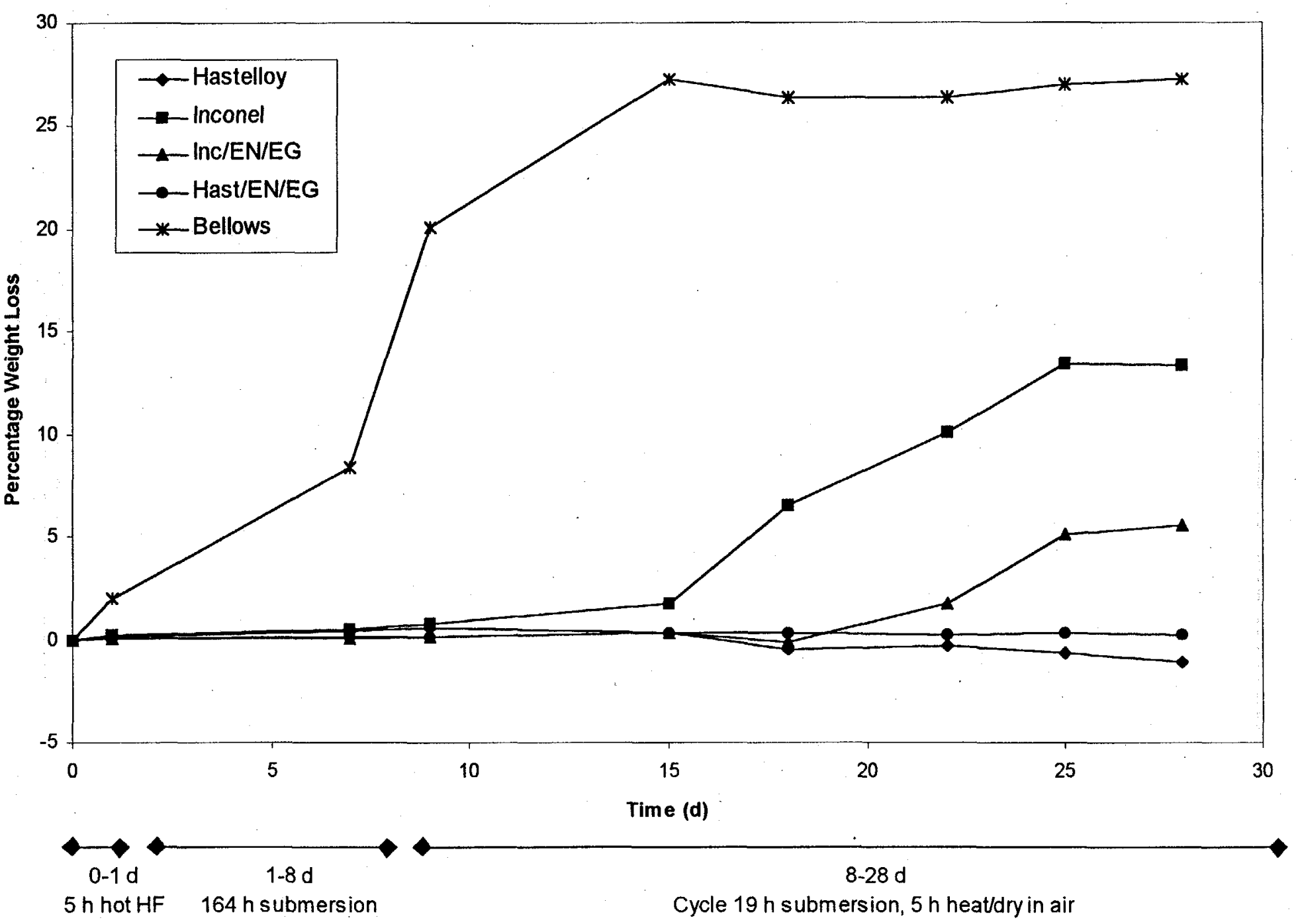


Table 2.1. Results from 5-h, 164-h, and 20-d corrosion tests

\begin{tabular}{|c|c|c|c|c|c|}
\hline \multirow{2}{*}{ Sample } & \multirow{2}{*}{ Plating pretreatment } & \multirow{2}{*}{$\begin{array}{c}\text { Original } \\
\text { weight (g) }\end{array}$} & \multicolumn{3}{|c|}{ Loss (Wt \%) } \\
\hline & & & $5 \mathrm{~h}$ & $164 \mathrm{~h}$ & $20 \mathrm{~d}$ \\
\hline Carbon steel & $\mathrm{EN}^{a} / \mathrm{EG}^{b} 5 \mathrm{~min}$ & 1.6375 & 0.0 & 0.18 & NA \\
\hline Hastelloy ${ }^{\oplus} \mathrm{C}-22$ tube & $\begin{array}{l}\text { Etch with } \mathrm{HCl} \text { and } \mathrm{FeCl}_{3} \\
\text { EN } 30 \text { min, } \mathrm{EG} 2 \mathrm{~min}\end{array}$ & 11.8371 & 0.02 & 0.06 & NA \\
\hline Hastelloy C-22 tube & $\begin{array}{l}\text { Concentrated } \mathrm{HCl}, \mathrm{EN} 30 \mathrm{~min} \text {, } \\
\text { EG } 5 \text { min }\end{array}$ & 5.5902 & 0.08 & 0.15 & NA \\
\hline Hastelloy C-22 tube & $\begin{array}{l}\text { Deburred; Concentrated } \mathrm{HCl} \text {, } \\
\text { EN } 60 \mathrm{~min} \text {, EG } 30 \mathrm{~min}\end{array}$ & 13.8448 & 0.02 & 0.11 & 0.19 \\
\hline Hastelloy C-22 tube & Deburred & 6.3088 & 0.11 & 0.42 & $(1.08)$ \\
\hline Inconel $^{\circledR}$ tube & $\begin{array}{l}\text { Concentrated } \mathrm{HCl} \text {, EN } 20 \mathrm{~min} \text {, } \\
\text { EG } 15 \mathrm{~min}\end{array}$ & 9.8467 & 0.29 & 0.84 & NA \\
\hline Inconel tube & $\begin{array}{l}\text { Etch } \mathrm{FeCl}_{3} \text { and Concentrated } \mathrm{HCl} \text {, } \\
\text { EN } 30 \mathrm{~min}, \mathrm{EG} 15 \mathrm{~min}\end{array}$ & 10.9577 & 0.11 & 0.66 & NA \\
\hline Inconel tube & $\begin{array}{l}\text { Deburred; Concentrated } \mathrm{HCl} \text {, } \\
\text { EN } 60 \mathrm{~min} \text {, EG } 30 \mathrm{~min}\end{array}$ & 12.8232 & 0.10 & 0.04 & 5.51 \\
\hline Inconel tube & Deburred & 8.2101 & 0.18 & 0.48 & 13.35 \\
\hline Inconel bellows & EN/EG plated & 28.9968 & 1.98 & 8.36 & 27.24 \\
\hline
\end{tabular}

${ }^{a} \mathrm{EN}$ - electroless nickel

${ }^{b} \mathrm{EG}$ - electroless gold

\subsection{HASTELLOY TUBING}

Four short samples of 0.5 -in.-diam Hastelloy tubing were tested. The first tube had been etched with concentrated hydrochloric acid $(\mathrm{HCl})$ and ferric chloride $\left(\mathrm{FeCl}_{3}\right)$ before being plated in electroless nickel for $30 \mathrm{~min}$ and electroless gold for $2 \mathrm{~min}$. The second tube was exposed only to concentrated $\mathrm{HCl}$ before being plated with electroless nickel for $30 \mathrm{~min}$ and electroless gold for $5 \mathrm{~min}$. Another tube was deburred before exposure to $\mathrm{HCl}$ and $1 \mathrm{~h}$ of electroless nickel plating, followed by $30 \mathrm{~min}$ of electroless gold plating. The last tube was used as a reference and came from the original stock with no pretreatment except deburring. These samples were submersed in $33 \mathrm{wt} \% \mathrm{HF}$ and heated to $60^{\circ} \mathrm{C}$ for $2 \mathrm{~h}$. They were allowed to cool in the HF for the next $3 \mathrm{~h}$ before being removed, rinsed, dried, and 
weighed. Although no corrosion was visible, the mean weight loss after exposure to HF for $5 \mathrm{~h}$ was $0.06 \mathrm{wt} \%$, an inconsequential amount.

After finishing the 5-h test, the samples were submersed in a new solution of $33 \mathrm{wt} \% \mathrm{HF}$ for $7 \mathrm{~d}$ $(164 \mathrm{~h})$. The mean weight loss was $0.105 \mathrm{wt} \%$, and no patches of nickel were visible. There was some bubbling (blistering) of the gold plating on the inside of the tubing near the edges that had not been deburred. These were long, thin areas that were raised as the HF somehow got under the gold and began reacting. The deburred piece and the untreated piece did much better and showed no corrosion effects. Solution from both the short- and intermediate-term testing remained clear and colorless.

The long-term testing proved to have little effect on any of the Hastelloy samples. Gold-plated samples and untreated samples both lost an inconsequential amount of weight $(<1 \mathrm{wt} \%)$, and the weight loss appeared to stabilize after formation of a thin coating of material. The unplated sample experienced a gain in weight as it was coated with a light-gray material.

\subsection{INCONEL TUBING}

Four short pieces of 0.5 -in.-diam Inconel tubing were tested. The tubes were prepared similarly to the Hastelloy tubing. The first tube was etched with concentrated $\mathrm{HCl}$ followed by $\mathrm{FeCl}_{3}$ before being plated with electroless nickel for $30 \mathrm{~min}$ and electroless gold for $15 \mathrm{~min}$. The second sample had been exposed to concentrated $\mathrm{HCl}$ before being plated with electroless nickel for $20 \mathrm{~min}$ followed by electroless gold for 15 min. Following the blistering of the edges in the first two samples, a third was deburred before plating with $1 \mathrm{~h}$ of electroless nickel and $30 \mathrm{~min}$ of electroless gold. The last sample was a piece of untreated Inconel tubing from the original stock. These samples were taken through the same $5-h$ test as were the Hastelloy pieces-but with much different results. The mean weight loss for the Inconel pieces after the 5-h test was $0.17 \mathrm{wt} \%$. The HF solution was light green, and there were silver spots on the outside of the tubing where the gold had been removed. The rate of corrosion of these samples is of some concern. Although only submerged for a relatively short time in the HF, the solution turned light green.

Results from the 7-d test were much the same as those from the 5-h test. The Inconel tubing turned the solution a bright green, and there was visible corrosion. Large areas of the gold were removed from the outside of the tubing, and the inside of the burred piece showed areas of bubbling (blistering) as did the Hastelloy. The bubbling was worse in the Inconel than in the Hastelloy and appeared to originate at the edge of the tubing and follow long thin pathways. The plating appeared to be fragile and come off easily in these areas. The deburred piece did somewhat better, although at the end of this test, it still showed signs of bubbling on the outside. 
The long-term test was difficult for all of the Inconel samples. Because of the strong corrosion on the burred piece of tubing, only the deburred and the untreated pieces were used in the long-term tests. The gold plating began to crack and blister after only $2 \mathrm{~d}$, and by day 7 had completely failed. The samples continued a steep weight loss during this testing phase for $17 \mathrm{~d}$ before finally forming a bright-green coating, which provided some protection. At the end of this time, the weight loss for the gold-plated sample was $5.1 \mathrm{wt} \%$, while the loss for the untreated sample was $13.4 \mathrm{wt} \%$.

\subsection{INCONEL BELLOWS}

The poorest performing sample was a gold-plated Inconel bellows from a solenoid valve. This sample experienced immediate and severe corrosion, which proceeded until it lost both ends at day 10 ( $2 \mathrm{~d}$ into the long-term test). It continued losing mass at a rapid pace until day 15 , when the mass loss reached a plateau. For the rest of the testing, the mass remained at $\sim 75 \mathrm{wt} \%$ of the original value, although the bellows continued to corrode and lose gold plating. 


\section{DISCUSSION}

Electroless gold has been proven to prolong the life of metals by shielding them from corrosion. Its usefulness for different metals in HF was questionable and was the major impetus for this series of tests. Electroless nickel and gold proved to be beneficial on all metals involved in this study. It clearly prolonge life by protecting the surfaces from the corrosive effects of HF. Although the plating eventually failed on most samples, it did prove to dramatically reduce the corrosion of Inconel and kept a coating from forming on the Hastelloy.

A sample of precipitate from the intermediate test was collected from gently scraping a deposit and the bottom of the bottle. The sample was rinsed and dried before it was sent for analysis by XRD. The sample was found to be a mix of predominately hydrous iron fluoride $\left(\mathrm{Fe}_{2} \mathrm{~F}_{5} \bullet 7 \mathrm{H}_{2} 0\right)$ and hydrous chromium fluoride $\left(\mathrm{CrF}_{3} \cdot 3 \mathrm{H}_{2} \mathrm{O}\right)$ with some unidentified minor phases

A few factors appeared to play a role in the life of the plating. It appears that the metal surface on which the gold is plated is important for the bonding of the electroless nickel and gold. The carbon steel had almost no corrosion, while the Inconel and Hastelloy samples, with the higher chromium content, did not fair as well. The second factor in the life of the gold plate is the mechanical preparation of the sample. Those that had smooth surfaces held the plating much better than those that had rough edges. This phenomenon was especially evident in observing the difference between the pieces of tubing that had been deburred and those that had not. Finally, it was shown that areas around welds are extremely susceptible to attack. Both welds on the plated Inconel bellows were lost in a short period of time.

This study shows that electroless gold is an appropriate coating to protect metals from the corrosive effects of HF during short-term exposures. The carbon-steel samples demonstrated the most dramatic case for plating. It is well documented that HF rapidly corrodes carbon steel, and that phenomenon was also seen in this study. The hooks which held the plated carbon-steel coupons had some plating on them, but the HF vapor alone was enough to eat through these holders in a matter of hours before completely dissolving what fell into the liquid, while the plated coupons were left unaffected.

The effects from long-term exposure of electroless gold-plated Inconel vs unplated Inconel strongly points toward gold plating. During our experiments there was an overall difference in mass loss of $\sim 8 \mathrm{wt} \%$ in the unplated vs the plated Inconel. The plating on one tube eventually broke down over time; however, the plating served its purpose during the short- and intermediate-term testing. 
The results from the Hastelloy samples are somewhat harder to interpret. Both samples lost $\sim 0.5 \mathrm{wt} \%$ before gaining a coating and stabilizing. The unplated sample showed slightly more weight gain and discoloration than the plated sample, yet neither gained nor lost significantly more than $1 \mathrm{wt} \%$ over the $28 \mathrm{~d}$ of testing. The coating that formed was not confirmed to be either a protective passivation coat or an adverse corrosion coat (i.e., rust). Further testing may provide insight into the benefits, if any, of the coating. 


\section{INTERNAL DISTRIBUTION}

1. R. D. Aigner

2. G. E. Chitwood

3. J. M. Cosgrove

4. G. D. Del Cul

5. R. L. Faulkner

6. D. J. Foster

7. M. H. Haghighi

8. A. S. Icenhour

9. R. T. Jubin

10. P. E. Osborne

11. B. A. Owen
12. L. D. Phillips

13. J. H. Platfoot

14. D. W. Simmons

15. L. M. Toth

16. J. R. Travis

17. D. F. Williams

18. Central Research Library

19. ORNL Laboratory Records 20-21. ORNL Laboratory Records-OSTI

22. CTD/ADM DMC-RC

23. Conversion Project Files

\section{EXTERNAL DISTRIBUTION}

24. Oak Ridge Industrial Plating, Inc., 105 Fordham Rd., Oak Ridge, Tennessee, 37830 
. 